\title{
Synthesis of Subphthalocyanine-Based Stopcock for Zeolite L
}

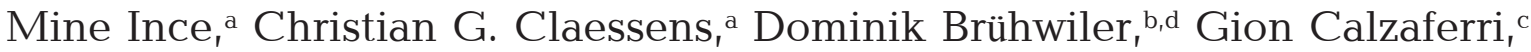 \\ and Tomás Torres ${ }^{\mathrm{a}}$
}

\section{Dedicated to Professor Michael Hanack on the occasion of his $80^{\text {th }}$ Anniversary}

\author{
a Departamento de Química Orgánica, Universidad Autonoma de Madrid, Cantoblanco, 28049 Madrid, Spain \\ ${ }^{\mathrm{b}}$ Institute of Inorganic Chemistry, University of Zurich, Winterthurerstrasse 190, 8057 Zurich, Switzerland \\ 'Department of Chemistry and Biochemistry, University of Bern, Freiestrasse 3, CH-3012 Bern, Switzerland \\ ${ }^{\mathrm{d} Z u r i c h}$ University of Applied Sciences, Einsiedlerstrasse 31, 8820 Wädenswil, Switzerland \\ ${ }^{\circledR}$ Corresponding authorE-mail: tomas.torres@uam.es
}

The synthesis and characterization of a subphthalocyanine derivative, bearing a rigid three-phenylene tail on peripheral position, as stopcock for potential selective adsorption to the channel entrances of zeolite L, is described.

Keywords: Subphthalocyanines, energy transfer materials, zeolite L, stopcocks.

\section{Introduction}

Natural photosynthesis comprises light absorption by a photonic antenna system followed by directional energy transfer to the reaction center. $^{[1]}$ The construction and development of similar artificial systems, which transfer energy from electronically excited molecules to a specific reaction centre via unexcited neighbour molecules is one of the most important goals of the fast-growing field of supramolecular electronics.

Energy transfer materials can be prepared by sequentially incorporating different types of organic dyes in the channels of zeolite L, a microporous material well suited for the preparation of host-guest composites. ${ }^{[2]}$ In these cases the entrances to the one-dimensional nanochannels of the zeolite L crystals are plugged with specific molecules called stopcocks composed of a rigid tail that can enter the channel and a head group that is too bulky to pass the pore opening. Upon selective excitation of the inner dyes, the energy travels via Förster Resonance Energy Transfer (FRET) to the stopcocks at the edges, which can now, for example transfer it to a photoelectronic or a photochemical device. Such artificial antenna materials are of particular interest in the design of sensitised organic solar cells. ${ }^{[2]}$

Phthalocyanines (Pcs) ${ }^{[3]}$ bearing rigid tails either in the axial or peripheral positions were shown to be efficient stopcock molecules for energy transfer applications in artificial photonic antenna systems..$^{[2,4]}$ Thus, efficient energy transfer occurs from the photoexcited dyes within zeolite L channels to the $\mathrm{ZnPc}$ stopcock molecules. Subphthalocyanines (SubPcs) ${ }^{[5]}$ are lower homologues of Pcs which are characterized by a $14-\pi$ electron non-planar aromatic macrocycle consisting of three diiminoisoindole units $N$-fused around a central boron atom. They have attracted much attention since their first synthesis by Meller and Ossko in 1972.[6] SubPcs have a particular cone-shaped structure in contrast with their related congeners the planar
Pcs, and therefore a lower tendency to aggregate. SubPcs have found applications in many research fields like light-emitting diodes,${ }^{[7]}$ photovoltaics,${ }^{[8]}$ nonlinear optics,${ }^{[9]}$ supramolecular chemistry, ${ }^{[10]}$ photosynthetic models, ${ }^{[11]}$ and photodynamic therapy, among others. ${ }^{[12]}$ The important photochemical advantage of this class of compounds is based on their strong light absorption in the visible region (500-700 nm) and their electronically rich $\pi$-conjugated system, which make them promising chromophores with potential applications in photosynthetic models for studying energy- and electrontransfer processes. ${ }^{[13]}$

We report herein the synthesis of new SubPc $\mathbf{1}$ as potential stopcock molecule for incorporation in zeolite L channels. Its structural formula is shown in Figure 1.

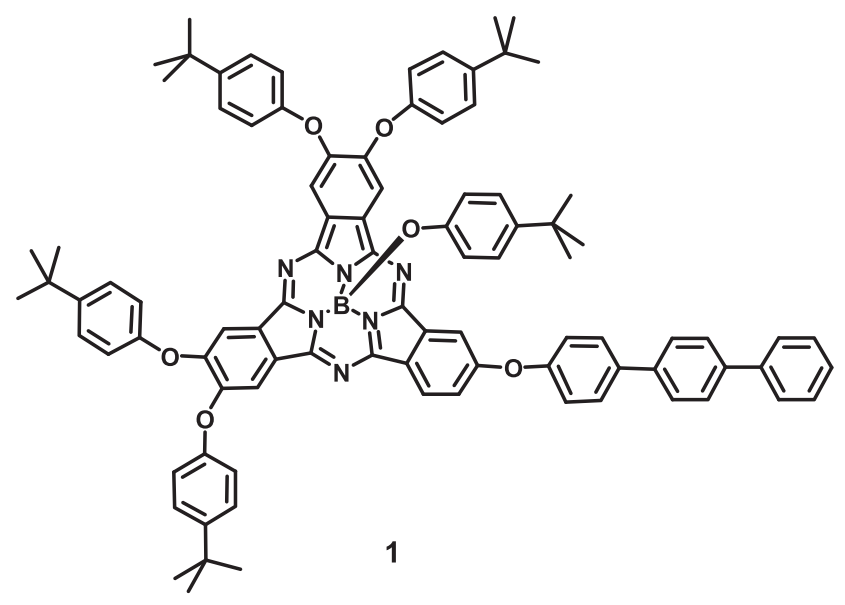

Figure 1. Structural formula of SubPc 1.

\section{Experimental}

All chemicals were purchased from Aldrich and used without further purification. 4,5-tert-butylphenoxyphthalonitrile 
was prepared according to a published procedure. ${ }^{[14]}$ All reactions were followed by TLC employing aluminium sheets coated with silica gel 60 F254 (Merck). ${ }^{1} \mathrm{H}$ NMR spectra were obtained using a Bruker Avance 300 spectrometer. UV-Vis spectra were recorded on a Hewlett-Packard 8453 instrument. Photoluminescence was measured with a Perkin-Elmer LS50B. Infrared spectra (IR) were recorded on a Bruker Vector 22; employing solid samples $(\mathrm{KBr}$ pressed disks). MALDI-TOF mass spectrum was obtained in a Voyager-DE STR mass spectrometer.

4-(4-Bromophenylphenoxy)phthalonitrile (4). In a typical procedure, a solution of 4-nitrophthalonitrile $(500 \mathrm{mg}, 2.88 \mathrm{mmol})$ and 4-bromo-4'-hydroxybiphenyl $(720 \mathrm{mg}, 2.9 \mathrm{mmol})$ in dry DMF $(25 \mathrm{~mL})$ was stirred under argon atmosphere at room temperature. After stirring for $15 \mathrm{~min}$, dry $\mathrm{K}_{2} \mathrm{CO}_{3}(620 \mathrm{mg}, 4.58 \mathrm{mmol})$ was added portionwise during $2 \mathrm{~h}$ with efficient stirring. The mixture was stirred under a argon atmosphere for $24 \mathrm{~h}$ at room temperature, added to ice water $(300 \mathrm{ml})$ thereafter. The precipitate was filtered off, washed with water, dried and recrystallized from methanol, obtaining $89 \mathrm{mg}$ of a white solid. Yield: $82 \%$. IR $(\mathrm{KBr}) v_{\max } \mathrm{cm}^{-1}$ : 2227, 1589, 1480, 1388, 1288, 1254, 1088, 848. ${ }^{1} \mathrm{H}$ NMR $\left(\mathrm{CDCl}_{3}\right.$, $298 \mathrm{~K}) \delta_{\mathrm{H}}$ ppm: $7.74(\mathrm{~d}, J=8.8 \mathrm{~Hz}, 1 \mathrm{H}), 7.63(\mathrm{~d}, J=8.4 \mathrm{~Hz}, 2 \mathrm{H})$, 7.59 (d, $J=8 \mathrm{~Hz}, 2 \mathrm{H}), 7.44$ (dd, $J=6.4 \mathrm{~Hz}, 2 \mathrm{H}), 7.32$ (d, $J=2.4$ $\mathrm{Hz}, 1 \mathrm{H}), 7.29\left(\mathrm{dd},{ }^{3} J=2.4,{ }^{4} J=8.8 \mathrm{~Hz} 1 \mathrm{H}\right), 7.29(\mathrm{~d}, J=8.8,2 \mathrm{H})$. 4-(4-Biphenylphenoxy)phthalonitrile (3). A suspension of 4-(4-bromophenylphenoxy)phthalonitrile 4 (300 $\mathrm{mg}, \quad 0.8$ $\mathrm{mmol}$ ), phenylboronic acid (133 mg, $1.09 \mathrm{mmol})$, tetrakis (triphenylphosphine)palladium(0) (50 $\mathrm{mg}, 0.04 \mathrm{mmol})$ and $\mathrm{Na}_{2} \mathrm{CO}_{3}$ (1.5 mL of a $2 \mathrm{~N}$ aqueous solution) in dimethoxyethane $(10 \mathrm{ml})$ was stirred under argon atmosphere overnight at $80^{\circ} \mathrm{C}$. The suspension was cooled to room temperature and poured onto a $1 \mathrm{~N} \mathrm{NH}_{4} \mathrm{Cl}$ solution $(100 \mathrm{ml})$. The mixture was extracted with ethyl acetate $(2 \times 100 \mathrm{ml})$ and the combined organic extracts were washed with brine $(20 \mathrm{ml})$, dried over $\mathrm{Na}_{2} \mathrm{SO}_{4}$ and evaporated in vacuo. The crude product was purified by column chromatography on silica gel (hexane- $\left.\mathrm{CHCl}_{3} 1: 2\right)$ to yield $119 \mathrm{mg}(40 \%)$ of a white solid. $m / z$ (MALDI-TOF) $372.1\left[\mathrm{M}^{+}\right]$. IR (KBr) $v_{\max } \mathrm{cm}^{-1}: 2229,1588$, $1483,1398,1285,1253,1163,892 .{ }^{1} \mathrm{H}$ NMR $\left(\mathrm{CDCl}_{3}, 298 \mathrm{~K}\right) \delta_{\mathrm{H}}$ ppm: 7.75-7.64 (m, 9H), 7.47 (t, $J=7.4 \mathrm{~Hz}, 2 \mathrm{H}), 7.39(\mathrm{~d}, J=9 \mathrm{~Hz}$, $1 \mathrm{H}), 7.34(\mathrm{~d}, J=3 \mathrm{~Hz}, 1 \mathrm{H}), 7.30\left(\mathrm{dd},{ }^{3} J=2.5,{ }^{4} J=8.9 \mathrm{~Hz} 1 \mathrm{H}\right), 7.16$ (d, $J=9 \mathrm{~Hz}, 2 \mathrm{H})$.

Subphthalocyanine 1. In a $25 \mathrm{~mL}$ two-necked round-bottomed flask, equipped with a condenser, magnetic stirrer and rubber seal,
$\mathrm{BCl}_{3}(1.05 \mathrm{~mL}, 1 \mathrm{M}$ solution in $p$-xylene) was added to mixture of 4,5-di-(p-tert-butylphenoxy)phthalonitrile (2) (300 mg, 0.70 $\mathrm{mmol}$ ) and 4-(4-biphenylphenoxy)phthalonitrile (3) (131 mg, 0.35 $\mathrm{mmol}$ ) under argon atmosphere. The reaction mixture was refluxed at $150^{\circ} \mathrm{C}$ for $2 \mathrm{~h}$. After cooling down to room temperature the unreacted $\mathrm{BCl}_{3}$ and solvent were quickly removed in vacuo. 4-tertButylphenol ( $795 \mathrm{mg}, 5.2 \mathrm{mmol})$ and dry toluene $(5 \mathrm{~mL})$ were added to the crude mixture and stirring was continued at $100^{\circ} \mathrm{C}$ for $3 \mathrm{~h}$. The solvent was removed by vacuum distillation and the solid was washed with a mixture of methanol/water (4:1). The compound was purified by column chromatography on silica gel using a mixture of hexane/ethyl acetate $(9: 1)$ as eluent to give $73 \mathrm{mg}(15 \%)$ of a reddish solid. $m / z$ (MALDI-TOF) 1380.6 [M ${ }^{+}$. HR-MALDI-TOFMS (Matrix: DCTB) calc. for $\mathrm{C}_{92} \mathrm{H}_{85} \mathrm{BN}_{6} \mathrm{O}_{6}[\mathrm{M}]^{+}: m / z: 1380.6588$, found 1380.6632. IR ( $\mathrm{KBr}) v_{\max } \mathrm{cm}^{-1}: 2923,1720,1508,1458$, 1215, $1173(\mathrm{~B}-\mathrm{O}), 823 .{ }^{1} \mathrm{H}$ NMR $\left(\mathrm{CDCl}_{3}, 298 \mathrm{~K}\right) \delta_{\mathrm{H}} \mathrm{ppm}: 8.72(\mathrm{~d}$, $J=9 \mathrm{~Hz}, 1 \mathrm{H}), 8.35(\mathrm{~s}, 1 \mathrm{H}), 8.27-8.26(\mathrm{~m}, 4 \mathrm{H}), 7.70-7.65(\mathrm{~m}, 8 \mathrm{H})$, $7.60(\mathrm{~d}, J=3 \mathrm{~Hz}, 1 \mathrm{H}), 7.58(\mathrm{~d}, J=3 \mathrm{~Hz}, 1 \mathrm{H}), 7.49-7.33(\mathrm{~m}, 12 \mathrm{H})$, 7.11-7.01 (m, 8H), $6.73(\mathrm{~d}, J=9 \mathrm{~Hz}, 2 \mathrm{H}), 5.23(\mathrm{~d}, J=9 \mathrm{~Hz}, 2 \mathrm{H})$, 1.38-1.35 (m, 36H), $1.06\left(\mathrm{~s}, 9 \mathrm{H}, \mathrm{CCH}_{3}\right.$ ax.). UV-Vis $\left(\mathrm{CHCl}_{3}\right) \lambda_{\max }$ (lge) nm: 573 (4.9), 516 (4.3), 356 (4.4), 282 (5.0).

\section{Results and Discussion}

SubPc 1 was prepared in $15 \%$ by cross cyclotrimerization of 4,5-di-(p-tert-butylphenoxy)phthalonitrile ${ }^{[14]} \mathbf{2}$ and 4-(4-biphenylphenoxy)phthalonitrile 3 in the presence of $\mathrm{BCl}_{3}$ (1 $\mathrm{M}$ solution in $p$-xylene), followed by substitution of the axial chlorine atom by tert-butoxyphenol (Scheme 1) in toluene. ${ }^{[15]}$ 4-(4-Biphenylphenoxy)phthalonitrile 3 was obtained in $40 \%$ yield by Suzuki cross-coupling reaction between 4-(4-bromophenylphenoxy)phthalonitrile 4 and phenylboronic acid in the presence of tetrakis(triphenylphosphine) palladium as catalyst in DME. ${ }^{[16]}$

SubPc 1 was purified by silica gel column chromatography and characterized by ${ }^{1} \mathrm{H}$ NMR spectroscopy, UV-Vis spectrophotometry, MALDI-TOF mass spectrometry, and FTIR spectroscopy. Compound $\mathbf{1}$ is soluble in both polar and non-polar organic solvents. SubPc 1 gave rise to a well-resolved ${ }^{1} \mathrm{H}$ NMR spectrum in $\mathrm{CDCl}_{3}$ (Figure 2).

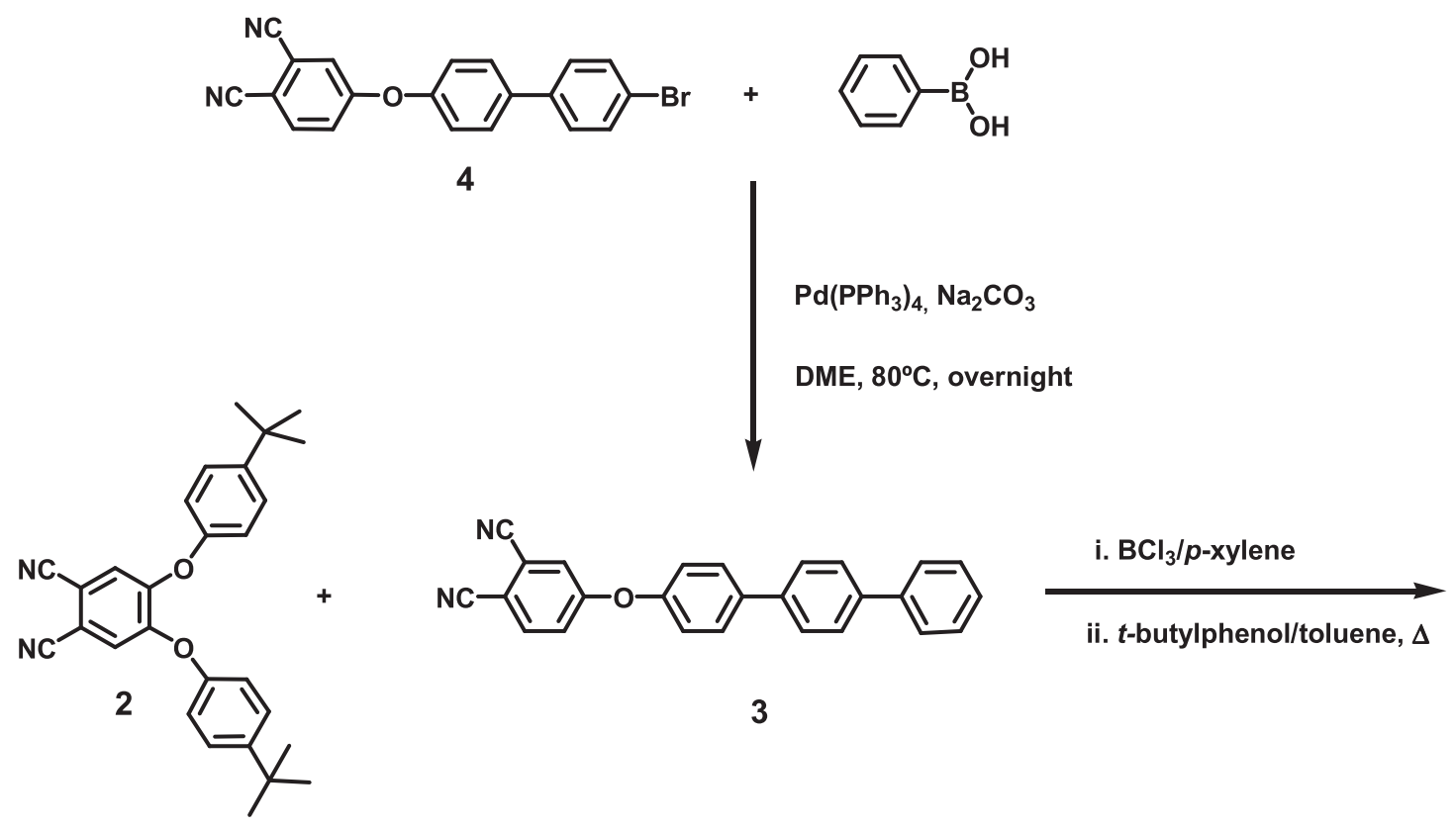

Scheme 1. Synthesis of subphthalocyanine $\mathbf{1 .}$ 


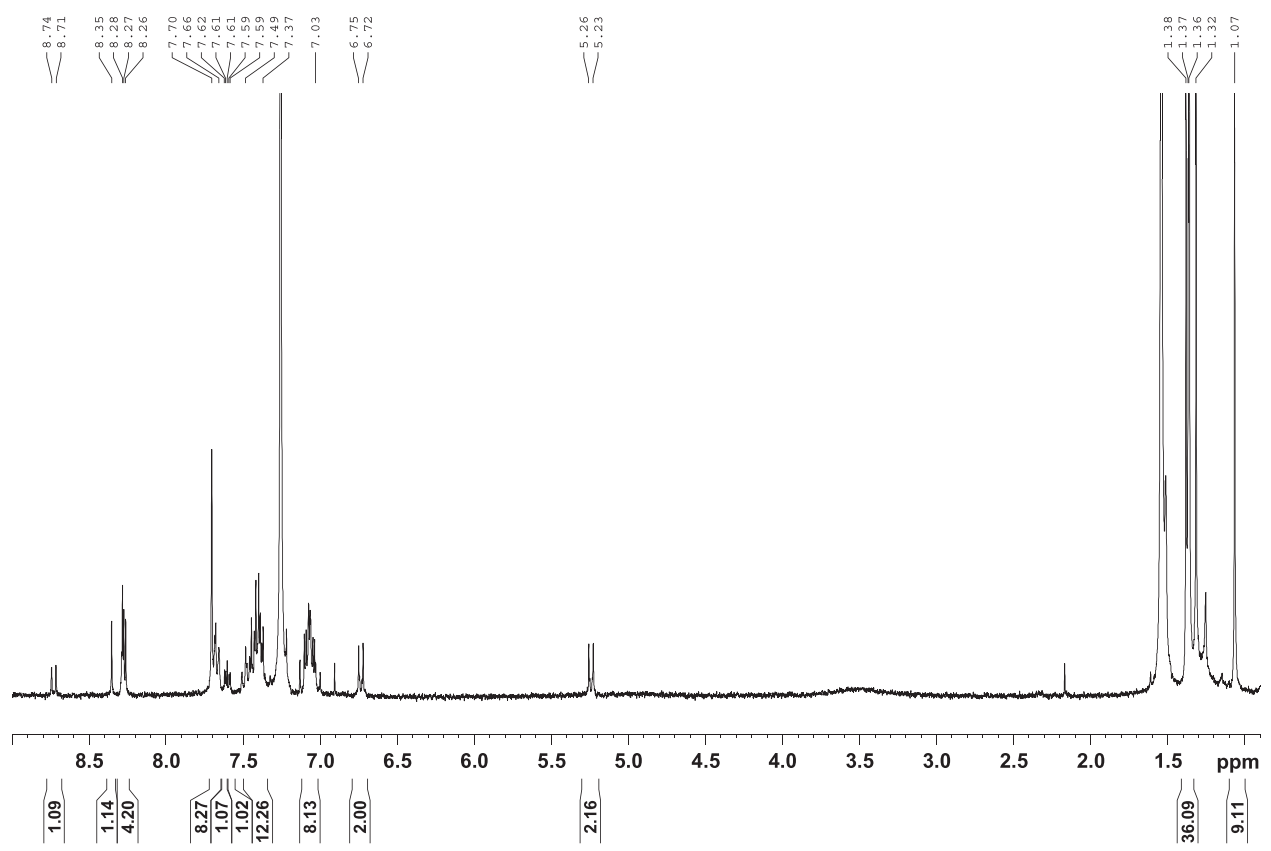

Figure 2. ${ }^{1} \mathrm{H}$ NMR spectrum of SubPc 1 in $\mathrm{CDCl}_{3}$.

All aromatic protons appear between 8.7-7.0 ppm, with the exception of the axial phenoxy ligand, whose signals are shielded at $5.3 \mathrm{ppm}$ corresponding to the protons close to the aromatic SubPc ring.

The UV-Vis spectrum of SubPc 1 (Figure 3), recorded in chloroform $\left(10^{-5} \mathrm{M}\right)$, was found to be essentially nonaggregated and characterized by a sharp absorption band in the $B$-band region at around $350 \mathrm{~nm}$, and in the $Q$-band region at $573 \mathrm{~nm}$, together with a vibronic shoulder at around $515-520 \mathrm{~nm}$. The bands are blue-shifted compared to those of Pcs owing to the smaller conjugated system (14 vs. $18 \pi$ electrons) and have lower absorption coefficients. The emission spectrum recorded at the excitation wavelength of $550 \mathrm{~nm}$ corresponding to the $Q$-band showed the expected mirror image with a maximum at $588 \mathrm{~nm}$ (Figure 3).

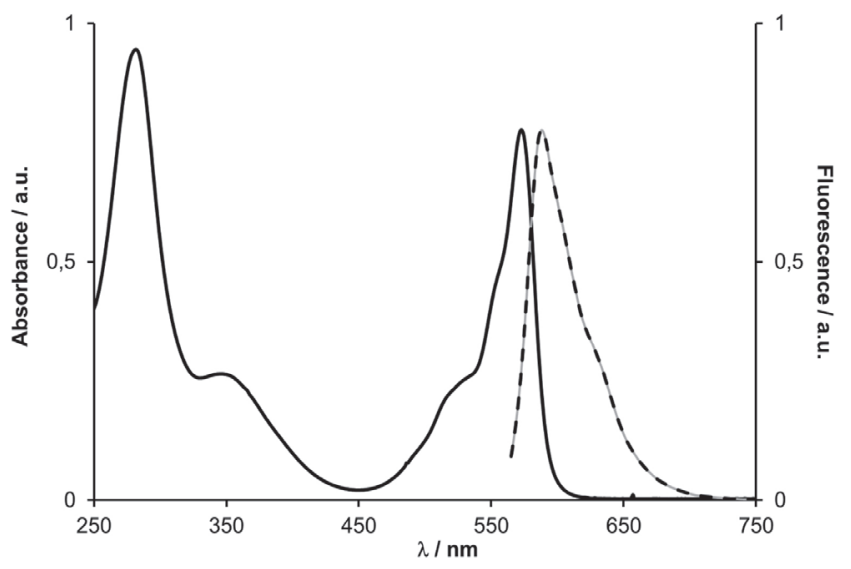

Figure 3. UV-Vis (plain line) and emission (dashed line, $\left.\lambda_{\text {exc }}=550 \mathrm{~nm}\right)$ spectra of SubPc $1\left(10^{-5} \mathrm{M}\right)$ in $\mathrm{CHCl}_{3}$.

Currently, photophysical experiments are carried out with different potential donor molecules, well suited as donors for FRET experiments, that can be excited in a spectral range where the stopcock SubPc 1 has a very weak absorption (around $450 \mathrm{~nm}$ ), and have emission spectra which overlap the SubPc absorption $Q$-band, giving rise to effective energy transfer.

In summary, we have described the synthesis of a novel SubPc dye $\mathbf{1}$ as potential stopcock molecule antenna for incorporation in zeolite L channels. The combination of the channel entrance of zeolite L with appropriate functionalized SubPc derivatives like $\mathbf{1}$ is expected to lead to valuable materials for optoelectronic applications.

Acknowledgements. This work has been supported by the Spanish MEC (CTQ-2008-00418/BQU and CONSOLIDER INGENIO 2010, CSD2007-00010) and the Comunidad de Madrid (MADRISOLAR-2, S2009/PPQ/1533).

\section{References}

1. Calzaferri G., Lutkouskaya K. Photochem. Photobiol. Sci. 2008, 7, 879-910.

2. Brühwiler D., Calzaferri G., Torres T., Ramm J.H., Gartmann N., Dieu L.-Q., López-Duarte I., Martínez-Díaz M.V. J. Mater. Chem. 2009, 19, 8040-8067.

3. (a) Claessens C.G., Hahn U., Torres T. Chem. Rec. 2008, 8, 75-97. (b) de la Torre G., Claessens C.G., Torres T. Chem. Commun. 2007, 2000-2015. (c) Bottari G., de la Torre G., Guldi D.M., Torres T. Chem. Rev. 2010, 110, 6768-6816.

4. (a) Dieu L-Q., Devaux A., López-Duarte I., Martínez-Díaz M.V., Brühwiler D., Calzaferri G., Torres T. Chem. Commun. 2008, 1187-1189. (b) Lopez-Duarte I., Dieu L-Q., Dolamic I., Martinez-Diaz M.V., Torres T., Calzaferri G., Brühwiler D. Chem. Eur. J. 2011, 17, 1855-1862.

5. (a) Torres T. Angew. Chem., Int. Ed. 2006, 45, 2834-2837. (b) Claessens C.G., González-Rodíguez D., Torres T. Chem Rev. 2002, 102, 835-853.

6. Meller A., Ossko A. Monatsh. Chem. 1972, 103, 150-155.

7. (a) Díaz D.D., Bolink H.J., Cappelli L., Claessens C.G., Coronado E., Torres T. Tetrahedron Lett. 2007, 48, 46574660. (b) Chen Y.-H., Chang Y.-J., Lee G.-R., Chang J.-H., Wu 
I.-W., Fang J.-H., Hsu S.-H., liu S.-W., Wu C.-I., Pi T.-W. Org. Electron. 2010, 11, 445-449.

8. (a) Gommans H., Gheyns D., Aernouts T., Girotto C., Poortmans J., Heremans P. Adv. Funct. Mater. 2007, 17, 26532658. (b) Mutolo K.L., Mayo E.I., Rand B.P., Barry P., Forrest S.R., Thompson M.E. J. Am. Chem. Soc. 2006, 128, 81088109. (c) Gommans H., Aernouts T., Verreet B., Heremans P., Medina A., Claessens C.G., Torres T. Adv. Funct. Mater. 2009, 19, 3435-3439.

9. (a) del Rey B., Keller U., Torres T., Rojo G., Agulló-López F., Nonell S., Marti C., Brasselet S., Ledoux I., Zyss J. J. Am. Chem. Soc. 1998, 120, 12808-12817. (b) Claessens C.G., González-Rodríguez D., Torres T., Martín G., Agulló-López F., Ledoux I., Zyss J., Ferro V.R., García de la Vega J.M. J. Phys. Chem. B. 2005, 109, 3800-3806.

10. (a) Claessens C.G., Torres T. J. Am. Chem. Soc. 2002, 124, 14522-14523. (b) Claessens C.G., Torres T. Chem. Commun. 2004, 1298-1299. (c) Claessens C.G., Vicente-Arana M.J., Torres T. Chem. Commun. 2008, 6378-6380.
11. González-Rodríguez D., Carbonell E., De Miguel Rojas G., Atienza Castellanos C., Guldi D. M., Torres T. J. Am. Chem. Soc. 2010, 132, 16488.

12. (a) Xu H., Jiang X-J., Chan E.Y.M., Fong W-P., Ng D.K.P. Org. Biomol. Chem. 2007, 5, 3987-3992. (b) Rubio N., JiménezBanzo A., Torres T., Nonell S. J. Photochem. Photobiol. A. 2007, 185, 214-219.

13. (a) Medina A., Claessens C.G., Rahman G.M.A., Lamsabhi A.M., Mo O., Yañez M., Guldi D.M., Torres T. Chem. Commun. 2008, 1759-1761. (b) González-Rodríguez D., Carbonell E., De Miguel Rojas G., Atienza Castellanos C., Guldi D. M., Torres T. J. Am. Chem. Soc. 2010, 132, 16488-16500.

14. Wöhrle D., Eskes M., Shigehara K., Yamada A. Synthesis 1993, 194-196.

15. Claessens C.G., González-Rodríguez D., del Rey B., Torres T., Mark G., Schuchmann H.-P., von Sonntag C., MacDonald J.G., Nohr R.S. Eur. J. Org. Chem. 2003, 14, 2547-2551.

16. Edsall R.J., Heather Jr., Harris A., Manas E.S., Mewshaw R.E. Biooorg. Med. Chem. 2003, 11, 3457-3474. 